\title{
Pretreated of banana pseudo-stem as raw material for enzymatic hydrolysis and bioethanol production
}

\author{
Kusmiyati $^{1, *}$ and Ryzka Pratiwi Sukmaningtyas ${ }^{2}$ \\ ${ }^{1}$ Renewable Energy Research Centre, Department of Chemical Engineering, Universitas Muhammadiyah Surakarta, Indonesia \\ ${ }^{2}$ Department of Chemical Engineering, Universitas Muhammadiyah Surakarta, Indonesia
}

\begin{abstract}
Development of alternative energy is needed to solve the energy problem, including bioethanol. Banana pseudo-stem is a lignocellulose material that can used to produce bioethanol. Banana pseudo-stem has $28.83 \%$ cellulose and $19.39 \%$ lignin. The amount of lignin will reduce by pretreatment process. Variations of pretreatment methods by autoclaving of banana-pseudo stem in a steam, $0.5 \mathrm{~N}, 1 \mathrm{~N}, 1.5 \mathrm{~N}, 2 \mathrm{~N} \mathrm{NaOH}$ solutions for 90 minutes were employed. Then the preteated samples were further enzymatic hydrolysed for 24, 48, 72 hours. The fermentation method of simultaneous saccharification and fermentation (SSF) was applied using cellulase enzyme and yeast of Saccharomyces cerevisiae for 120 hours. The variation of the pretreatment process by increasing of $\mathrm{NaOH}$ concentration solutions led to decreased the lignin content while increased in cellulose content. The lowest lignin content was $11.44 \%$ and the highest cellulose was $51.66 \%$. The highest sugar content was $29.8 \mathrm{~g} / \mathrm{L}$ (at pretreatment $2 \mathrm{~N} \mathrm{NaOH}$ solution, 72 hours hydrolysis). The highest bioethanol amount $(4.32 \mathrm{~g} / \mathrm{L})$ was produced from pretreated banana stem using $2 \mathrm{~N} \mathrm{NaOH}$ solution. Keywords: bioethanol, banana pseudo-stem, alkali pretreatment, enzymatic hydrolysis, SSF, Saccharomyces cerevisiae
\end{abstract}

\section{Introduction}

One of the problems that appear in Indonesia is decreasing crude oil as a main source of energy. Development of renewable energy is needed to solve the problem of energy limitation, one way is a bioethanol development.

Bioethanol is made from raw materials such as fibers, molasses, fruits, and other materials that containing reduction sugar which can be fermented [1]. Second generation bioethanol is produced from lignocellulose material. The process of conversion lignocellulose material to bioethanol generally consists of pretreatment, hydrolysis, and fermentation [2].

Alkaline pretreatments are more effective to dissolve lignin than acid and hydrothermal process [3], due to decrease of cellulose crystallinity and increasing access for enzymes [4]. The most alkaline used are $\mathrm{NaOH}, \mathrm{KOH}$, $\mathrm{Ca}(\mathrm{OH})_{2}$, and ammonia [5].

Banana pseudo-stem is one of lignocelllulosic material that could be fermented to ethanol. According to [6], banana pseudo-stem $44 \%$ cellulose, and $8.1 \%$ lignin on a dry basis.

Saccharomyces cerevisiae is generally used in ethanol production industries. $S$. cerevisiae has tolerance to substrate concentration, high ethanol content, low $\mathrm{pH}$, and low oxygen levels [1].

The aims of this study were to investigate the influence of pretreatment variation (autoclaving pretreatments of banana stem in steam, $0.5 \mathrm{~N}, 1 \mathrm{~N}, 1.5 \mathrm{~N}$,
$2 \mathrm{~N} \mathrm{NaOH}$ solutions) on the cellulose, hemicellulose, and lignin contents of the pretreated materials. Subsequently, the effect of the pretreatments on glucose from hydrolysis process and bioethanol contents from fermentation were also evaluated.

\section{Materials and Methods}

\subsection{Pretreatment}

Dry banana pseudo-stem was cut to a size $5 \mathrm{~cm}$, milled and sieved up to 60 mesh then dried at $140{ }^{\circ} \mathrm{C}$ to reduce the remaining moisture content. Alkaline solution (99\% $\mathrm{NaOH}$, Merck) was added to 25 gr of dry banana pseudostem placed in a $250 \mathrm{~mL}$ beaker glass to form a slurry. The concentrations of $\mathrm{NaOH}$ were $0.5 \mathrm{~N}, 1 \mathrm{~N}, 1.5 \mathrm{~N}$, and $2 \mathrm{~N}$. Pretreatment of the slurries was carried out for 90 minutes in the autoclave at $121^{\circ} \mathrm{C}$.

\subsection{Saccharomyces cerevisiae preparations}

S. cerevisiae was cultivated on agar slant containing 10 $\mathrm{g} / \mathrm{L}$ glucose, $5 \mathrm{~g} / \mathrm{L}$ peptone, $3 \mathrm{~g} / \mathrm{L}$ yeast extract, $20 \mathrm{~g} / \mathrm{L}$ agar at $28{ }^{\circ} \mathrm{C}$ [7]. The inoculum of $S$. cerevisiae was cultivated on culture medium containing $50 \mathrm{~g} / \mathrm{L}$ glucose, $1 \mathrm{~g} / \mathrm{L} \quad(\mathrm{NH} 4)_{2} \mathrm{HPO} 4, \quad 0.5 \mathrm{~g} / \mathrm{L} \quad \mathrm{KH}_{2} \mathrm{PO}_{4}, 0.25 \mathrm{~g} / \mathrm{L}$ $\mathrm{MgSO}_{4} .7 \mathrm{H}_{2} \mathrm{O}, 10 \mathrm{~g} / \mathrm{L}$ peptone, $10 \mathrm{~g} / \mathrm{L}$ yeast extract, at 30 ${ }^{\circ} \mathrm{C}$ for 24 hours [8].

\footnotetext{
*Corresponding author: kusmiyati@ums.ac.id
} 


\subsection{Enzymatic Hydrolysis}

5 grams of pretreated banana pseudo-stem was added with citrate buffer solution at $\mathrm{pH} 5$ (solid:solution ratio 1:10) then added with one gram of cellulase (SQzyme CS; $20,000 \mathrm{u} / \mathrm{g}$ ). The hydrolysis process was carried out in rotary shaker water bath at $50^{\circ} \mathrm{C}, 150 \mathrm{rpm}$ for 24,48 , and 72 hours.

\subsection{Ethanol Fermentation}

Ethanol fermentation was carried out by simultaneous saccharification and fermentation (SSF) process. The treated banana pseudo-stem was added with $100 \mathrm{~mL}$ of citrate buffer at solid concentration $10 \%(\mathrm{w} / \mathrm{v})$, then sterilized at $121^{\circ} \mathrm{C}$ for 15 minutes. Cellulase enzim at a dosage $20 \mathrm{FPU} / \mathrm{g}$ dry solid and $10 \%(\mathrm{v} / \mathrm{v})$ yeast $S$. cerevisiae was added to the samples of the pretreated banana-stem solution. The ratio of cellulase and yeast 1:5 (w/v). SSF process was performed at $37.5^{\circ} \mathrm{C}$ for 120 hours.

\subsection{Distillation}

After the fermentation process is complete, the fermentation product is then distilled to separate the ethanol from impurities.

\subsection{Analysis}

Analysis of lignin content was done by Klason method [9]. 1 gr dry sample (A) was extracted with alcohol benzene (ratio 1:2). The sample was transferred to a 50 $\mathrm{mL}$ beaker glass and $15 \mathrm{~mL}$ of $72 \%$ sulfuric acid was added at $20^{\circ} \mathrm{C}$ with stirring for $2-3$ minutes and then idle for 2 hours. Then it was added with $300 \mathrm{~mL}$ of distilled water in a $100 \mathrm{~mL}$ erlenmeyer flask. The sample then was added to distilled water up to $575 \mathrm{~mL}$ (3\% sulfuric acid concentration). It was boiled and leave for 4 hours at low heating. Sample was washed until the lignin acid-free was obtained then dried at $105^{\circ} \mathrm{C}$, cool in desicator and weigh up to constant weight (B).

$$
\text { lignin content }=\frac{\mathrm{B}}{\mathrm{A}} \times 100 \%
$$

Analysis of cellulose and hemicellulose content was done by Chesson method [10]. 1 gr dry sample (A) refluxed with $150 \mathrm{~mL}$ of distilled water at $100^{\circ} \mathrm{C}$ for 2 hours. The result is filtered, the residue is washed until neutral and dried (B). Dried residue refluxed with $150 \mathrm{~mL}$ of $0.5 \mathrm{M}$ sulfuric acid at $100^{\circ} \mathrm{C}$ for 2 hours. The result is filtered and dried (C). Dried residue treated with $10 \mathrm{~mL}$ of $72 \%$ sulfuric acid at room temperature for 4 hours, then diluted to $0.5 \mathrm{M}$ sulfuric acid and refluxed at $100^{\circ} \mathrm{C}$ for 2 hours. The result is filtered, the residue washed and dried (D).

$$
\begin{gathered}
\text { hemicellulose content }=\frac{\mathrm{B}-\mathrm{C}}{\mathrm{A}} \times 100 \% \\
\text { cellulose content }=\frac{\mathrm{C}-\mathrm{D}}{\mathrm{A}} \times 100 \%
\end{gathered}
$$

Analysis of glucose content was done by photometric method. Sample of $0.01 \mathrm{~mL}$ added with $1 \mathrm{~mL}$ of glucose reagent then incubated at photometer (BA-88A, Mindray) for 1 minute at $37^{\circ} \mathrm{C}$.

Analysis of ethanol content was done by Gas Chromatography (GC) method. On the GC tool (Clarus 680, Perkin Elmer), the injector temperature is set to $130^{\circ} \mathrm{C}$, the detector temperature $150^{\circ} \mathrm{C}$, initial temperature $80^{\circ} \mathrm{C}$, initial time 1 minute at heating rate $5^{\circ} \mathrm{C} /$ minute, final time 5 minutes.

\section{Results and Discussion}

\subsection{Effect Different $\mathrm{NaOH}$ Concentration of Pretreatments on Lignin, Cellulose, and Hemicellulose Contents}

Pretreatment process was carried out to decrease lignin content and increase cellulose content on banana stem. Physical and chemical processes were carried out by using grinding and autoclaving the banana stem using a steam or $\mathrm{NaOH}$ solution.

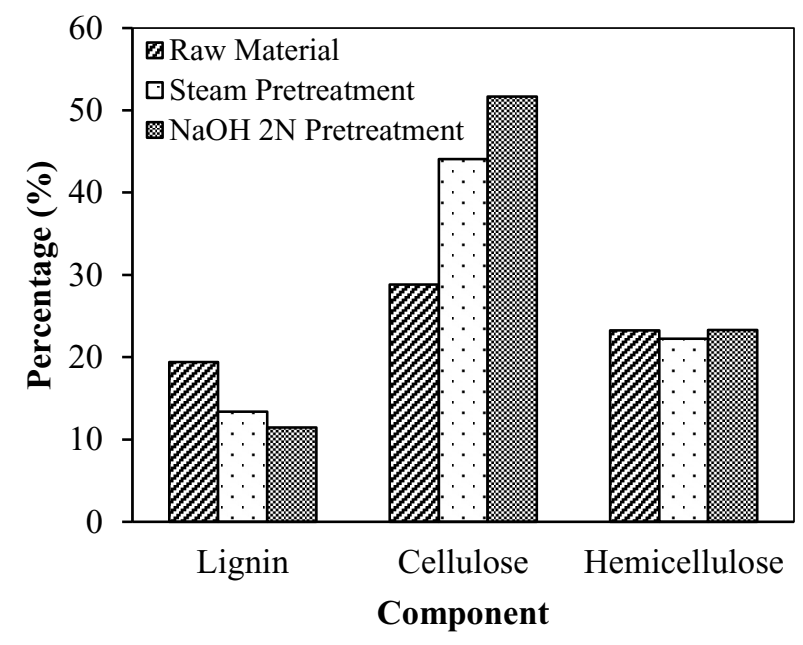

Fig. 1. Effect of pretreatments on lignin, cellulose, and hemicellulose contents. Pretreatment conditions at banana pseudo-stem: liquid ratio (1:4) autoclaved for 90 minutes.

Fig. 1 shows the optimal pretreatment was obtained using autoclaving banana stem in $2 \mathrm{~N} \mathrm{NaOH}$ solution that resulted lignin content $11.44 \%$, cellulose $51.66 \%$, and hemicellulose $23.29 \%$. Lower cellulose was observed for steam pretreatment sample that yielded $13.37 \%$ lignin and $44.10 \%$ cellulose. While, for untreatment banana stem resulted the lowest cellulose that yielded $19.39 \%$ lignin and $28.83 \%$ cellulose. Physical pretreatment causes some hemicellulose degrades and lignin decomposes, while chemically is degrading the hemicellulose and dissolving lignin [11].

In the study by [12], pretreatment using alkali can increase cellulose content up to $8-10 \%$. Moreover, the increase of $\mathrm{NaOH}$ concentration can give a significant influence to lignin degradation [13]. 


\subsection{Effect of Different Pretreatments and Hydrolysis Time to Glucose Content}

The hydrolysis process is aimed to convert cellulose into glucose which is then converted to bioethanol. The enzyme hydrolysis was carried out using $2 \%(\mathrm{w} / \mathrm{w})$ cellulase enzyme with $5 \mathrm{gr}$ of pretreated banana stem at $50{ }^{\circ} \mathrm{C}$. Different pretreatment and time of hydrolysis on glucose content were investigated.

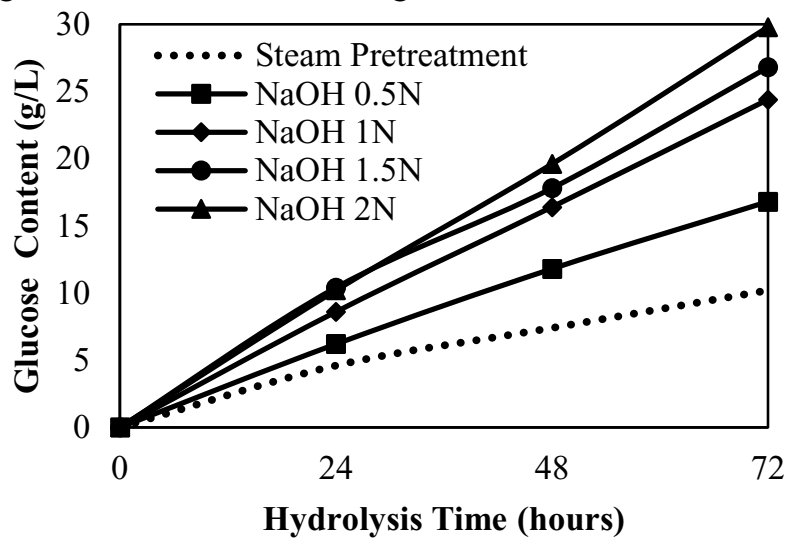

Fig. 2. Effect of different pretreatments and hydrolysis time on glucose content. Enzymatic hydrolysis at solid: liquid ratio 1:10 (w/v), $50{ }^{\circ} \mathrm{C}, 150 \mathrm{rpm}, \mathrm{pH} 5$.

Fig. 2 shows the optimum glucose content obtained at banana stem pretreated with autoclaving in $2 \mathrm{~N} \mathrm{NaOH}$ solution for 72 hours hydrolysis that resulted $29.8 \mathrm{~g} / \mathrm{L}$ glucose. Different pretreatments show that the glucose increased with increasing time. However the highest glucose were obtained at $72 \mathrm{~h}$ hydrolysis time that resulted $10.2 \mathrm{~g} / \mathrm{L}$ for stem pretreatment, $16.8 \mathrm{~g} / \mathrm{L}$ for $\mathrm{NaOH} 0.5 \mathrm{~N}$ pretreatment, $24.4 \mathrm{~g} / \mathrm{L}$ for $\mathrm{NaOH} 1 \mathrm{~N}$ pretreatment, $26.8 \mathrm{~g} / \mathrm{L}$ for $\mathrm{NaOH} 1.5 \mathrm{~N}$ pretreatment. The higher $\mathrm{NaOH}$ solution increased glucose from hydrolysis was similar with studied reported by [14].

\subsection{Effect of Different Pretreatments on Bioethanol Concentration}

The fermentation process was performed by Simultaneous Saccharification and Fermentation (SSF) method on 10 gram banana pseudo-stem by adding $100 \mathrm{~mL}$ of citrate buffer, 2\%(w/w) cellulase enzyme, and 1:1 (w/v) $S$. cerevisiae at $37.5^{\circ} \mathrm{C}$ for 120 hours.

The highest bioethanol was observed on banana stem pretreated using $\mathrm{NaOH} 2 \mathrm{~N}$ solution that yielded $4.32 \mathrm{~g} / \mathrm{L}$ ethanol. Ethanol content increased with increasing $\mathrm{NaOH}$ concentration in the pretreatment of banana stem. The increasing of ethanol due to cellulose content of banana increased with increasing $\mathrm{NaOH}$ concentration. The cellulose was converted to reduction sugar at hydrolysis process followed by fermentation of the sugar to bioethanol. Alkali pretreatment can increase ethanol concentration was also reported by a study by [15].

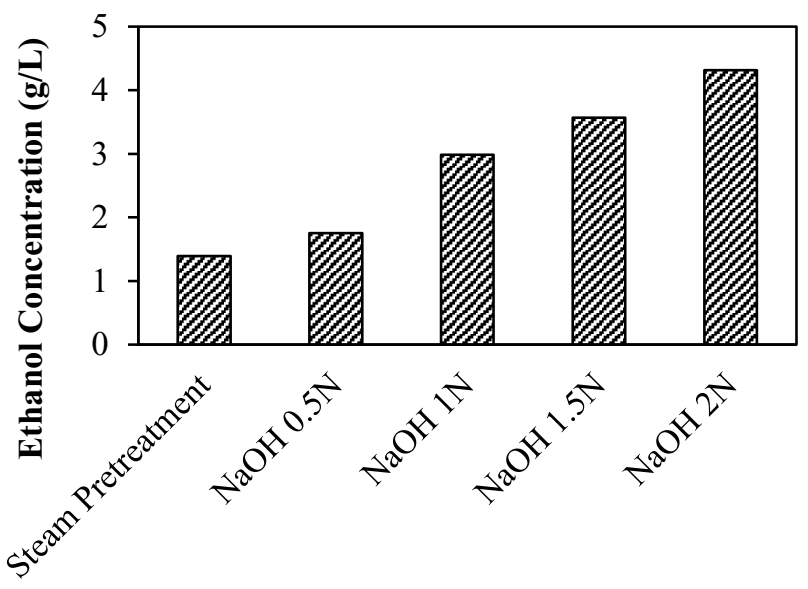

\section{Sample}

Fig. 3. Effect of $\mathrm{NaOH}$ concentration on bioethanol concentration. SSF conditions at 1:10 (w/v) raw material and citrate buffer ratio, $2 \%(\mathrm{w} / \mathrm{w})$ cellulase enzyme, 1:1 (w/v) $S$. cerevisiae, $37.5^{\circ} \mathrm{C}, \mathrm{pH} 5,120$ hours.

\section{Conclusions}

Different alkaline concentration of pretreatment can affect to the lignin, cellulose, and hemicellulose contained in banana pseudo-stem. It can also affect the ethanol content that is obtained from fermentation. Hydrolysis time also affected to glucose content from hydrolysis. The glucose content increased with increasing of hydrolysis time. The best result from pretreatment process were $11.44 \%$ lignin, $51.66 \%$ cellulose, and $23.29 \%$ hemicellulose from sample that pretreated by autoclaving banana stem in $2 \mathrm{~N} \mathrm{NaOH}$. The highest result from hydrolysis process was $29.8 \mathrm{~g} / \mathrm{L}$ glucose at 72 hours hydrolysis using sample pretreated by autoclaving using $2 \mathrm{~N} \mathrm{NaOH}$ that resulted $4.32 \mathrm{~g} / \mathrm{L}$ ethanol.

The authors would like to thank the Directorate of Research and Community Service, Ministry of Education, Technology and Higher Education Indonesia (Kemenristekdikti) for funding this Research (PB Kompetensi 2017).

\section{References}

1 E. Akponah, O. O. Akpomie, and M. Ubogu, "Bioethanol Production from Cassava Effluent using Zymomonas mobilis and Saccharomyces cerevisiae Isolated from Rafia Palm (Elaesis guineesi) SAP," Eur. J. Exp. Biol., 3, 247-253 (2013).

2 E. C. Bensah and M. Mensah, "Chemical Pretreatment Methods for the Production of Cellulosic Ethanol: Technologies and Innovations," Int. J. Chem. Eng., 2013, 1-21 (2013).

3 P. Alvira, E. Tomás-Pejó, M. Ballesteros, and M. J. Negro, "Bioresource Technology Pretreatment technologies for an efficient bioethanol production process based on enzymatic hydrolysis : A review," Bioresour. Technol., 101, 4851-4861 (2010).

4 R. M. Trevorah and M. Z. Othman, "Alkali Pretreatment and Enzymatic Hydrolysis of Australian Timber Mill Sawdust for Biofuel Production," $J$. 
Renew. Energy, 2015, 1-9 (2015).

5 S. H. Mood et al., "Lignocellulosic biomass to bioethanol, a comprehensive review with a focus on pretreatment," Renew. Sustain. Energy Revoews, 27, 77-93 (2013).

6 E. L. Souza, G. F. Liebl, C. Marangoni, N. Sellin, M. S. Montagnoli, and O. Souza, "Bioethanol from Fresh and Dried Banana Plant Pseudostem," Chem. Eng. Trans., 38, 271-276 (2014).

7 L. Peng and Y. Chen, "Conversion of Paper Sludge to Ethanol by Separate Hydrolysis and Fermentation (SHF) using Saccharomyces cerevisiae," Biomass and Bioenergy, 35, 1600-1606 (2011).

8 F. A. Gonçalves, H. A. Ruiz, E. S. dos Santos, J. A. Teixeira, and G. R. de Macedo, "Bioethanol Production by Saccharomyces cerevisiae, Pichia stipitis and Zymomonas mobilis from Delignified Coconut Fibre Mature and Lignin Extraction According to Biorefinery Concept," Renew. Energy, 94, 353-365 (2016).

9 M. Bunzel, A. Schüßler, and G. T. Saha, "Chemical characterization of Klason lignin preparations from plant-based foods," J. Agric. Food Chem., 59, 12506-12513 (2011).

10 R. Datta, "Acidogenic fermentation of lignocellulose-acid yield and conversion of components," Biotechnol. Bioeng., 23, 2167-2170 (1981).

11 K. Eisenhuber, K. Krennhuber, V. Steinmüller, and A. Jäger, "Comparison of Different Pre-Treatment Methods for Separating Hemicellulose from Straw during Lignocellulose Bioethanol Production," Energy Procedia, 40, 172-181 (2013).

12 M. Idrees, A. Adnan, F. Malik, and F. A. Qureshi, "Enzymatic Saccharification and Lactic Acid Production from Banana Pseudo-Stem Through Optimized Pretreatment at Lowest Catalyst Concentration," EXCLI J., 12, 269-281 (2013).

13 N. I. Iberahim, J. M. Jahim, S. Harun, M. T. M. Nor, and O. Hassan, "Sodium Hydroxide Pretreatment and Enzymatic Hydrolysis of Oil Palm Mesocarp Fiber," Int. J. Chem. Eng. Appl., 4, 101-105 (2013).

14 D. Dahnum, S. O. Tasum, E. Triwahyuni, M. Nurdin, and H. Abimanyu, "Comparison of SHF and SSF Processes using Enzyme and Dry Yeast for Optimization of Bioethanol Production from Empty Fruit Bunch," Energy Procedia, 68, 107-116 (2015).

15 S. Thakur, B. Shrivastava, S. Ingale, R. C. Kuhad, and A. Gupte, "Degradation and selective ligninolysis of wheat straw and banana stem for an efficient bioethanol production using fungal and chemical pretreatment," 3 Biotech, 3, 365-372 (2013). 